\title{
Jan Ryszard Sielezin, W kręgu myśli politycznej polskiego ruchu ludo- wego. Artykuły i szkice
}

\author{
Muzeum Historii Polskiego Ruchu Ludowego w Warszawie, Warszawa 2018, 252 ss. \\ DOI: $10.19195 / 1643-0328.26 .16$
}

Profesor dr hab. Jan Ryszard Sielezin jest pracownikiem Instytutu Politologii Uniwersytetu Wrocławskiego. Jest znanym i rozpoznawalnym w środowisku naukowym badaczem i nauczycielem akademickim. Jego zainteresowania badawcze obejmują szeroki obszar dociekań naukowych: od opozycji politycznej okresu PRL, służb specjalnych, stosunków państwo-Kościół, aż po metodologię badań naukowych. Zajmuje się też współczesnymi ruchami społecznymi i kwestiami regionalnymi. Jego dorobek naukowy jest imponujący — opublikował ponad 350 artykułów naukowych i popularno-naukowych, a także 18 książek.

Tym razem pochylił się nad problematyką myśli politycznej polskiego ruchu ludowego. Wydana przez Muzeum Historii Polskiego Ruchu Ludowego w Warszawie publikacja zawiera w sumie 12 artykułów i szkiców problemowych. Choć kilka z tych tekstów zostało napisanych jakiś czas temu, to nadal mają one aktualną wartość poznawczą i naukowo-badawczą. Przede wszystkim winny skłaniać do refleksji nie tylko politologicznej, lecz także historycznej i metodologicznej.

Konstrukcja pracy jest właściwa metodologicznie i nie budzi zastrzeżeń merytorycznych. Publikacja składa się ze wstępu, 12 artykułów tematycznie ujętych w sposób problemowy. Zakres chronologiczny pracy obejmuje II Rzeczpospolitą, okres wojny i okupacji (1939-1945) oraz pierwsze lata Polski Ludowej (1945-1947). Publikacja zawiera ponadto posłowie pióra dra Janusza Gmitruka, wykaz ośmiu pierwodruków oraz wyczerpującą, a zarazem przejrzystą bibliografię. Poza tym zamieszczone zostały w niej też przydatne w pracy źródła archiwalne, 27 pozycji źródeł drukowanych i 20 tytułów prasowych. Znajduje się tu również spis ważniejszych tytułów encyklopedii i leksykonów. Z kolei spis literatury zawiera aż 265 pozycji. Autor zamieścił w nim ponadto kilka bezcennych źródeł rękopiśmiennych. W tym kontekście trzeba zaznaczyć, iż prof. Sielezin starał się niczego nie pominąć, co mogłoby pomniejszyć poziom merytoryczny i metodologiczny publikacji. Co istotne, wyselekcjonował pozycje najbardziej znaczące, adekwatne do treści i wątków tematycznych. Zamieszczony na końcu indeks nazwisk znacznie ułatwia czytelnikom poruszanie się w niełatwej przecież problematyce.

W pierwszym artykule, noszącym tytuł Idea państwa w myśli politycznej ruchu ludowego w II Rzeczypospolitej, autor - wykorzystując różnorodne źródła i opracowania - stawia wiele ciekawych i trafnych konkluzji badawczych. Stwierdza na przykład, iż na założeniach programowych dotyczących istoty państwa zaciążyły różne obiektywne czynniki, między innymi podziały polityczne w ruchu ludowym i polityka obozu sanacyjnego. Wskazuje na istotną rolę chłopów w państwie, którzy dostrzegali potrzebę koniecznych reform w państwie. Ma niewątpliwie rację, 
że hasło „Żywią i bronią” stało się w okresie dwudziestolecia międzywojennego symbolem chłopskiej dumy i doniosłej roli chłopów w państwie i społeczeństwie (s. 21-22).

Drugi artykuł nosi tytuł Wizja państwa w myśli politycznej partii chłopskich w II Rzeczypospolitej. Na podstawie różnorodnych źródeł, w tym drukowanych, autor dokonuje tu trafnej analizy ewolucji programowej, ale też prezentowanych postaw ideowo-politycznych czołowych wówczas partii i ugrupowań ruchu ludowego. Warta odnotowania jest konkluzja badacza, iż w PSL od kongresu zjednoczeniowego w 1931 roku dokonała się istotna ewolucja programowa. Autor ma rację co do tego, że w ostatnim okresie II Rzeczypospolitej ruch ludowy nie odwoływał się do radykalnych form walki z sanacją. Zapewne uznano wówczas, iż w warunkach zagrożenia państw ze strony III Rzeszy najważniejszą kwestią była konsolidacja narodu i przygotowanie się do obrony państwa.

Trzeci tekst dotyczy Determinantów polskiej myśli politycznej okresu II wojny światowej ze szczególnym uwzględnieniem ruchu ludowego. Jak już wcześniej wspomniałem, autor jest bardzo dociekliwy i konsekwentny. W swoich dywagacjach i analizach naukowych stara się nie pominąć żadnej znaczącej pozycji naukowej. Jednocześnie na uwagę zasługuje umiejętność właściwej selekcji; wydobycia tych wątków badawczych, które coś istotnie wnoszą do dorobku myśli politycznej tego okresu. Nie ucieka też od trudnych, często kontrowersyjnych kwestii ideowo-politycznych. Wielokrotnie w swojej publikacji sygnalizuje zjawisko „silnego oddziaływania propagandowo-politycznego PPR popieranego przez Kreml”. Słusznie dostrzega zjawisko nasilających się różnorodnych presji komunistów wobec opozycyjnych ugrupowań ruchu ludowego. Powodowało to między innymi polaryzację w szeregach partii chłopskich. W tym kontekście konfrontacja PRL-owskiej (często marksistowskiej) „literatury naukowej” z tą wydawaną po 1989 roku wydaje się niezwykle naukowo potrzebna, a zarazem poznawcza! Zdaje się to konieczne nie tylko z punktu widzenia prawdy historycznej, ale i obiektywności, rzetelności warsztatowej i uczciwości naukowej. Kwestie te autor śmiało podnosi i akcentuje, co może tylko z korzyścią wyjść dla dobra nauki.

Kolejny artykuł zatytułowano Wizja Paneuropy gospodarczej w myśli politycznej Stronnictwa Ludowego „Roch” (1941-1943). Zdaniem badacza klęski militarne Niemiec, wzrost pozycji politycznej i militarnej ZSRR na arenie międzynarodowej, ale też decyzje podjęte w Jałcie zmusiły ludowców do weryfikacji dotychczasowych projektów utworzenia w Europie Środkowo-Wschodniej „Paneeuropy gospodarczej”. Trudno też nie zgodzić się z tezą autora, że ludowcy zbytnio przywiązywali wagę do zasad i koncepcji agraryzmu, a niekiedy wykazywali brak elastyczności i konsekwencji w polityce społeczno-gospodarczej. Wydaje się jednak, że głównymi przyczynami erozji i polaryzacji ruchu ludowego stały się czynniki polityczne. W konsekwencji doprowadziły one do podziału na dwie zwalczające się partie chłopskie. Po likwidacji PSL i powstaniu ZSL nastąpiło niestety zniszczenie na długie lata tożsamości politycznej ruchu ludowego. W tym kontekście nasuwa się istotny dla badaczy dylemat do rozważenia - czy w ówczesnej sytuacji politycznej ludowcy z PSL mogli tym zjawiskom przeciwdziałać i zrobić coś więcej?

W artykule Koncepcje polityczno-ustrojowe ruchu ludowego w latach 1939-1945 prof. Sielezin stwierdza, że w okupowanym kraju proces konsolidacji postępował wolniej z powodu różnic taktyczno-programowych. W swoich rozważaniach skupia się na najważniejszym ugrupowaniu chłopskim - SL „Roch”. Ludowcy byli świadomi trudności, na jakie napotykali w nowej rzeczywistości ustrojowo-politycznej. Podziały w ruchu ludowym i zbliżenie SL „Wola Ludu” z PPR skomplikowały sytuację w strukturze „Rocha” i pogłębiły podziały w ruchu ludowym. W konsekwencji SL „Roch” przekształcił się w PSL, a lubelskie SL zaczęło uzurpować sobie prawo do 
reprezentowania całego ruchu ludowego (s. 82-83). W tej sytuacji powrót do systemu sprzed wojny, do którego odwoływał się „Roch”, okazał się nierealny.

Kolejny tekst nosi tytuł Przemyślenia i koncepcje przyszłości w programach ruchu ludowego w okresie wojny i okupacji (1939-1945). Według autora prezentowały one programy na różnym poziomie ogólności i uszczegółowienia. Słabością ruchu ludowego było jego rozdrobnienie i podziały. Jedynie SL „Roch” jako najbardziej popularne na wsi ugrupowanie mogło liczyć w przyszłości na szersze poparcie (s. 114).

W artykule Poglady i propozycje w programie organizacji terenowych $i$ władz naczelnych PSL w latach 1945-1946 dotyczace reform ustrojowo-politycznych w Polsce badacz podkreśla wzrost znaczenia PSL, która aspirowała do przejęcia w sposób legalny władzy w państwie. Stronnictwo to lansowało ogólnonarodowy, a zarazem atrakcyjny program ustroju społeczno-politycznego i gospodarczego. Miał on być jednak wolny od komunistycznych wpływów i ograniczeń. Uwarunkowania polityczne w kraju i sytuacja międzynarodowa uniemożliwiały jednakże realizację tego programu. Chociaż stronnictwo przegrało batalię o władzę, program partii nie stracił na aktualizacji. Jest ono wciąż obecny w polityce (s. 132).

Tytuł następnego artykułu dotyczy Idei prawa i praworządności w programie PSL (1945-1947). Autor zauważa, że mimo klęski w walce o suwerenność i podmiotowość narodu wiele koncepcji dotyczących tej problematyki okazało się trwałych i aktualnych do dziś. Na uwagę zasługują ponadto rozważania badacza w rozdziale Ziemie Zachodnie i Północne Polski w wizji politycznej PSL(1945-1946). Konteksty i podteksty. Nie ulega bowiem wątpliwości, że lata 1948-1949 należy uznać za początek agonii i samodzielnej myśli ludowej. Pomimo tego wizja propagowana przez to stronnictwo nie wyszła z obiegu, a wiele idei i koncepcji w programie partii Mikołajczyka nabrało z czasem nowego znaczenia. Dla przykładu wciąż aktualne są koncepcje dotyczące funkcjonowania prawa i praworządności, gwarancji demokratycznego rozwoju narodu, idee neoagraryzmu, na które od 1989 roku powołują się terenowe organizacje odrodzonego PSL (s. 167).

Kolejna podjęta tematyka - Ziemie Odzyskane w myśli politycznej PSL (1945-1946) — stała się stałym elementem gry politycznej wykorzystywanym doraźnie przez obóz komunistyczny przeciwko PSL. Mikołajczyk i inni ludowcy wiele razy wypowiadali się pozytywnie o Ziemiach Zachodnich, zwłaszcza odnośnie do przejęcia poniemieckich terenów. Tym samym dostrzegali w tej kwestii szansę rozwoju kraju. Autor swoje rozważanie dokumentuje, wykorzystując szerokie zbiory archiwalne i prasę PSL (na przykład „Gazetę Ludową”).

W artykule Wizja rozwoju gospodarczego Ziem Odzyskanych w programie PSL (1945-1946) badacz konkluduje, iż zaostrzająca się walka polityczna w drugiej połowie 1946 roku doprowadziła do ograniczenia wpływów w PSL w radach narodowych i organizacjach samorządowych. Miało to niekorzystny wpływ na ogólną sytuację społeczno-polityczną na Ziemiach Zachodnich i Północnych. Kiedy zawodziły parlamentarne metody oddziaływania na „blok”, wówczas posłowie opozycyjnego PSL nasilali krytykę. Zapewne łudzili się jeszcze, że wywołany wydźwięk propagandowy wpłynie na wynik wyborów, a także wymusi korzystny kierunek przemian na Ziemiach Zachodnich (s. 202).

Ostatnia część dotyczy kwestii Agraryzmu w myśli politycznej polskiego ruchu ludowego (do 1947 roku). Autor w swoich dociekaniach sięga do samych źródeł agraryzmu, czyli do XVIII wieku. Postulowany przez PSL model społeczno-gospodarczy państwa zawierał również wątki agrarystyczne. Co więcej, w myśl tego programu Polska powinna być państwem rolniczo-przemysłowym. Dlatego mogłaby odegrać ważną rolę w europejskiej gospodarce aprowizacyjnej. Autor przychylnie i z uznaniem utożsamia się z niezwykle atrakcyjnym programem Polskiego Stronnictwa Ludowego. Niestety nasilający się terror UB i MO uniemożliwiły realizację celów, 
jakie stawiało sobie PSL. Trzeba też dodać, iż działacze PSL niekiedy traktowali agraryzm jako oręż walki ideologicznej. Podejmowali próby jego odnowy choćby z pozycji światopoglądowych (zobacz między innymi artykuły w „Chłopskim Świecie” z 1946 roku).

W sumie we wszystkich rozdziałach prof. Sielezin w sposób twórczy, a zarazem otwarty analizuje i rozwija postawione sobie dylematy i wątki badawcze. Z uznaniem trzeba podkreślić niezwykle wysoki poziom erudycyjny i warsztatowy wywodów i konkluzji zasygnalizowanych przez autora książki.

Na bliższą uwagę zasługuje też posłowie Janusza Gmitruka, dyrektora Muzeum Historii Polskiego Ruchu Ludowego. Jego rozważania w szczególny sposób wpisują się bowiem w przypadającą w tym samym roku co wydanie publikacji rocznicę odzyskania przez Polskę niepodległości. Nie sposób zaprzeczyć tezie autora, iż „Polityczny ruch chłopski to dziecko polskiej demokracji. Zrodziły go dwie wielkie idee-niepodległości i sprawiedliwości społecznej” (s. 223). Ludowcy konsekwentnie reprezentowali pogląd, iż dyktat jednej partii politycznej nie jest dobry zarówno dla państwa, jak i dla narodu. Dlatego też w ciągu dziesięcioleci w ruchu ludowym ukształtowały się pozytywne wzorce osobowe jego działaczy. Dzięki tym cechom ludowców chłopski ruch polityczny przetrwał najtrudniejsze okresy w dziejach. Doktor Janusz Gmitruk w swoich końcowych rozważaniach akcentuje niezwykle pozytywne i twórcze walory i wartości recenzowanej publikacji.

Reasumując powyższe wywody, należy stwierdzić, iż recenzowana książka jest ze wszech miar potrzebna i przydatna w obszarze myśli politycznej. Pomimo pokaźnej ilości publikacji poświęconych myśli politycznej ruchu ludowego to ujęcie ich w jednotematyczne dzieło (artykuły i szkice) jest pomysłem pożądanym, a wręcz koniecznym. Trzeba też zauważyć, że znajomość literatury odnoszącej się do poruszanych tematów również nie jest wystarczająca. Poza tym nierzadko jest ona wybiórcza czy o różnym poziomie merytorycznym i metodologicznym. Dlatego wydana publikacja jest niezwykle przydatna i potrzebna, zwłaszcza dla początkujących badaczy. Dotyczy to również studentów politologii, historii i innych pokrewnych kierunków studiów. Recenzowana książka może pomóc także działaczom ludowym w kwestiach postrzegania prezentowanych założeń programowych także w ujęciu całościowym. Ci ostatni mogą czerpać z opracowania wiele programowych pomysłów i koncepcji ideowo-politycznych, które wciąż nie straciły na aktualności. 